\author{
Mirosława Mycawka \\ Uniwersytet Jagielloński, Kraków \\ miroslawa.mycawka@uj.edu.pl
}

\title{
FORMACJE Z SUFIKSEM -S TYPU NORMALS, TERYTORIALS, TOTALS
}

\begin{abstract}
Słowa klucze: zapożyczenia leksykalne, anglicyzmy, derywacja słowotwórcza, sufiks -s Keywords: lexical borrowings, Anglicisms, word-formation, the $-s$ suffix
\end{abstract}

W ostatnim czasie w zbiorach nowego słownictwa można odnotować niewielką serię wyrazów, które, nie wnikając w szczegóły, charakteryzują się tym, iż kończą się na -als. Lista zarejestrowanych jednostek wraz z przykładami użycia i ustalonymi przeze mnie definicjami znaczeniowymi obejmuje następujące leksemy:

lokals 'członek lokalnej społeczności; tubylec':

Pomogę wam dogadać się z lokalsami. (TVP I 12 X 2017, serial Ojciec Mateusz); Nic dziwnego, że powstałe w takich okolicznościach dzieło nie cieszy obdarowanych nim lokalsów. (GP 2018, nr 9); [...] nowo otwarty Hotel Europejski znów stał się atrakcyjnym miejscem, goszcząc zagranicznych dygnitarzy i gwiazdy [...]. Lokalsi mieli prawo głównie do kawiarni, barku kawowego [...] i słynnej nocnej knajpy Kamieniołomy. (DRz 2018, nr 20); Mówiąc o swoim mieście, lokalsi częściej używają nazwy skróconej Joburg albo Jozi. (GP 2018, nr 28); Czy siedzące przy sąsiednim stoliku opalone blondynki popijające aperol [...] to lokalsi. (DRz 2018, nr 31); Grunt, że lokalsi wiedzą, o co chodzi, i w razie czego da się dopytać o drogę. (GP 2018, nr 39); A jednak stwierdza, że co wolno „lokalsowi”, tego nie ma prawa zrobić podróżnik [...]. (DRz 2018, nr 39); [...] lokalsi złożyli petycję przeciwko Marszowi Równości [...]. (PN 2019, nr 9); Lokalsi żądają interwencji. [...] Apelowali m.in. [...] strażacy, straż graniczna i lokalne samorządy. (GP 2019, $\mathrm{nr}$ 19); Na wielkie bitwy z policją, by wesprzeć lokalsów, zjeżdżają się zawodowi rewolucjoniści z całej Italii. (DRz 2019, nr 31); Liderzy 
lewicy [...] wydają się [...] z miotania gromów na niedorastających do postępu lokalsów czerpać niekłamane zadowolenie. (DRz 2019, nr 34); Miliony turystów zadeptują miejsca, które pragnęli zwiedzić. Lokalsi mają ich dość. (DRz 2019, nr 37).

millennials/millenials/milenials (ang. millennial - zwykle w liczbie mnogiej: millennials) 'członek pokolenia urodzonego w latach 8o. lub 9o. XX w.':

Sporą rolę odgrywają tu milenialsi, czyli młodzi ludzie urodzeni na przełomie stuleci, w wolnej Polsce. [...] Milenialsi dorastali w latach bezprecedensowego awansu materialnego i cywilizacyjnego Polski. (DzP 2016, nr 156); Przewaga Clinton wśród Latynosów, Afroamerykanów i tzw. millenialsów [...] nie była tak duża, jak przewidywały sondaże. (DzP 2016, nr 263); Milenialsi to pokolenie ludzi urodzonych po 1984 r. (WS 2017, nr 19); [...] indoktrynacja [...] zdaje się nie pustoszyć ich umysłów w takim stopniu jak millenialsów [...]. (WG 2018, nr 13); Pokolenie Y lub milenialsi: urodzeni między 1977 a 1995 r., czyli pokolenie rozpieszczone przez baby boomersów, leniwe i nastawione na natychmiastowe zaspokojenie swoich potrzeb. (S 2018, nr 5); Millenialsi rozpoczynający dorosłe życie w znacznie trudniejszych warunkach niż poprzednie pokolenia [...]. (NCz 2018, nr 21-22); Milenialsi, czyli pokolenie urodzone między 1981 a 1996 r., to według Pew Research Centre najbardziej lewicowa generacja w historii Ameryki. (S 2019, nr 9).

\section{naturals}

1. 'dziecko poczęte w sposób naturalny':

Jak przyszłam do niego na pierwszą wizytę cztery lata temu, to powiedział, że w moim przypadku to tylko in vitro i zaprasza, jak już będę w ciąży. Oczywiście powiedział, że zawsze może zdarzyć się naturals, ale na to mała szansa. (agnes_m, www.znanylekarz.pl, 30 XI 2012); [...] jak miałaś owulację, to przecież naturals może się trafić. (Jugosława, https://www.babyboom.pl/forum/temat/sta raczki-weteranki-2018-naszym-rokiem.79203/page-533);

2. środ. 'zwolennik naturalnego jeździectwa (ang. natural horsemanship); naturalny':

Klasycy kontra Naturalsi - po której stronie jesteś? Klasycy kontra Naturalsi? Jednym zarzuca się łamanie koni, drugim rozpuszczanie ich i stwarzanie niebezpiecznych sytuacji. [...] Naturalsi z większym pojęciem starają się odwzorować zachowania i reguły panujące wśród koni. [...] Niestety zdarzają się tacy Naturalsi, którzy gubią swoją misję i uważają, że stwarzanie sytuacji zagrażających życiu jest dla konia zwyczajnym byciem sobą. (https://eqst.pl/klasycy-kontra-naturalsi); Już po raz drugi na terenie „ANKA RANCHO” odbył się Piknik Naturalsów, impreza dla wszystkich, którzy cenią sobie bezsiłowe porozumienie z koniem... (http://hejna kon.pl/?p=22375); Znam osobiście kilka osób parających się metodami naturalnymi [...]. Wydaje mi się, że mało jest „naturalsów”, którzy potrafią rzeczowo i bez pogardy rozmawiać z klasykami. (Lena); dla mnie naturals to człowiek $\mathrm{PNH}^{1}$ (ElaPe);

$1 \quad$ PNH - Parelli Natural Horsemanship - szkoła naturalnego jeździectwa oparta na budowaniu więzi między człowiekiem a koniem dzięki zrozumieniu natury i psychologii tych zwierząt. 
problem w tym, ze „naturalnych”, ktorzy robia cos dobrze nie znam [...] a „dobrego naturalsa” widzialam na kilku filmikach na youtube (katija) ${ }^{2}$; Kurczę, poznałam tyle fajnych osób zajmujących się naturalem, [...] w szeroko pojętym „naturalu” zazwyczaj są ludzie w jakiś sposób ograniczeni (Sierra); Dlaczego „naturalsi” wzbudzają tyle kontrowersji? (Cejloniara) (http://re-volta.pl/forum/index.php?topic=11961.o).

\section{normals ${ }^{3}$}

1. 'człowiek normalny, żyjący według ogólnie przyjętych norm’:

Główny bohater [...] jest pod względem życia „normalsem”. Ma żonę, dziecko, żadnych ekscesów. (GPC 2016, nr 222);

2. 'osoba o umiarkowanych poglądach, nieangażująca się w spory polityczne i niespecjalnie interesująca się polityką’:

Liderzy Platformy wiedzą jednak, że samym radykalnym elektoratem wyborów się nie wygrywa, że trzeba przekonać tzw. normalsów. (DRz 2019, nr 42); [...] PiS ma dzisiaj tak duży i różnorodny elektorat, że znajdują się w nim także wyborcy mniej zdecydowani. To tzw. normalsi, którzy na co dzień nie żyją polityką i nie emocjonują się nią. (DRz 2019, nr 41); Czy „normalsi” wpłyną na wynik wyborów? [tytuł] Nie interesujesz się polityką, ale czujesz, że w twoim kraju mimo dobrej sytuacji jest coś nie tak? Nie lubisz skrajności prawicowych ani lewicowych? Irytują cię spory światopoglądowe i nie wiesz, czy będziesz głosować? Jeśli tak, to być może należysz do grupy normalsów - grupy wyborców, po którą chciałaby sięgnąć opozycja, a konkretnie Koalicja Obywatelska. [...] Termin „normals” pojawił się całkiem niedawno w tekście Agaty Bielik-Robson w „Gazecie Wyborczej”. Jej zdaniem normals ma konserwatywno-liberalne poglądy i nie chce angażować się w wojnę kulturową, którą proponuje lewa i prawa strona, a konkretniej - lewicowy i prawicowy populizm. To istotne, bo uformowanie się bloku Lewicy sprawia, że możliwe jest nawigowanie między podziałem lewica - prawica. (https://www.rp.pl/Plus-Minus-na-wybory/190909728-Czy-normalsi-wplyna-na-wynik-wyborow.html); [...] po raz pierwszy od dawna nie udało się wykreować podzialu na „normalsów” i „oszołomów”. [...] Jest szansa na pozyskanie nowych normalsów. (WS 2014, nr 23); PiS idzie po normalsów [tytuł] (GW 19 I 2018); Przerażona „Wyborcza” alarmuje, że PiS idzie po normalsów, przyznając tym samym, iż ludzie, którzy mają w nosie jazgot o „śmierci demokracji” [...], to ludzie normalni. (DRz 2018, nr 5); Czas pokaże, czy więcej w stolicy normalsów czy totalsów. (WG 2018, nr 40); [...] nie wszyscy mieszkańcy stolicy to ludzie metryką sięgający końca XIX wieku, więźniowie, czy też ludzie ogarnięci antypisowską obsesją. Sporo jest jeszcze normalsów. (GP 2018, nr 40); Lansowanie takich twarzy opozycji jak Paweł Kasprzak czy Maria Lempart immunizowało „normalsów” na

2 Zachowano pisownię oryginalną.

3 Terminu normals używał w latach 6o. minionego wieku amerykański socjolog Erving Goffman (2005) na określenie ludzi nienaznaczonych piętnem. Warto odnotować też, że nazwę Normalsi przyjął działający od 1999 r. łódzki zespół rockowy. 
wszelkie działania antypisu, nawet wtedy, gdy uważają, że władza rzeczywiście „jedzie po bandzie". (DRz 2018, nr 33); Liczą, że w końcu wyprowadzeni z równowagi normalsi nie wytrzymają i tak jak w Warszawie ktoś oberwie po pysku. (S 2018, nr 37); [...] opozycji szłoby znacznie lepiej, gdyby nie Michnik i jego klony, pracowicie utrwalające podział na samolubne elity kontra normalsi z PiS. (S 2018, nr 38); [...] „twardy rdzeń" radykalizuje się do absurdu, odpychając co normalniejszych, co powiększa frustrację „twardego rdzenia” i skłania do jeszcze większej radykalizacji, która odpycha kolejnych „normalsów” - i tak da capo al fine. (DRz 2019, nr 39); Nie mam wrażenia, że pan Wojciech Pszoniak [...] i reszta opozycyjnych celebrytów w swoich filmikach obrazili chorych umysłowo - jeśli ktoś powinien czuć się urażony, to normalsi, którym żyje się we współczesnej Polsce dobrze i nie czują potrzeby uczestnictwa w wyborach. (S 2019, nr 40); Wychodzi spoza tego celebryckiego świata do tak zwanych normalsów. (DzP 8 IX 2019); Wygląda na to, że Konfederacja przetrwała wyborczą porażkę. Trwa przebudowa ugrupowania. Moim zdaniem potrzeba więcej „normalsów” w pierwszej linii. (NCz 2019, nr 25-26);

3. środ. 'przedstawiciel subkultury normcore, cechującej się swobodnym, niewyszukanym i niezróżnicowanym płciowo stylem ubierania się’

Normalsi - posthipsterska „rewolucja” [tytuł] Normalsi, bo tak przyjęło się mówić na miłośników tego niewyszukanego stylu, wierni są prostej zasadzie, że niemodnie jest być modnym. [...] Szare bluzy, ogrodniczki i t-shirty i reklamująca je naturalna młodziutka siostra Kate Moss - to styl normalsów w wersji „posh”. [...] Normalsi kochają dżins w (prawie) każdej formie: oversize’owe kurtki, męskie kamizelki, koszule i spodnie. (https://www.elle.pl/artykul/normalsi-posthipsterska-rewolucja?page=4); Normcore - trend „na normalsa”, czyli jak być modnym będąc poza modą [tytuł] Bycie normalsem w szarej bluzie „no-name” pozwala poczuć się częścią wspólnoty, nie walczyć desperacko o wyróżnienie się z tłumu. (kobieta.gazeta.pl http:// kobieta.gazeta.pl/kobieta/1,107881,15902812,normcore-trend-na-normalsa-czylijak-byc-modnym-bedac-poza.html); Pełna (sub)kultura - czyli przewodnik dla normalsów! /Normalsi (szaraki)/ Niczym się nie wyróżniają, wiodą zwykłe życie. Jest ich chyba 90 procent. Chcą mieć święty spokój i tyle pieniędzy, żeby nie zamartwiać się od pierwszego do pierwszego, co niestety rzadko im się udaje. (http://podroze.gazeta.pl/podroze/1,113845,2204621.html); normals, potocznie: reprezentant uniseksowego stylu w modzie, charakteryzującego się niewyszukanymi, zwyczajnymi strojami; normcorowiec (https://sjp.pl/normals);

4. 'osoba heteroseksualna':

Szkoła tylko dla normalsów [tytuł] (https://www.wprost.pl/tygodnik/10078508/Szko la-tylko-dla-normalsow.html); Para heteroseksualnych Brytyjczyków walczy w sądzie o zawarcie związku partnerskiego [tytuł] Jako normalsi mają nikłe szanse. (http://wyborcza.pl/1,75399,19497385,para-heteroseksualnych-brytyjczykow-walczyw-sadzie-o-zawarcie.html); Wynika z niego, że geje i lesbijki mają bardziej pozytywne i szczęśliwe relacje z partnerem niż osoby heteroseksualne. [...] Tak pewnie jest, ponieważ nie chodzi im o te straszne dzieci, o ten rozwój świata. Są wolni od ob- 
ciążeń, które mają normalsi [...]. (https://zwierciadlo.pl/seks/debata-czy-orientacjama-znaczenie-2); Parady Równości [...] nie budują przecież obrazu homoseksualisty jako człowieka, który poza swą seksualną odmiennością jest również wartościowany jak inni. Przeciwnie - wtłaczają społeczeństwu przekonanie, że homo to dziwadło, odmieniec, okazujący „normalsom” pogardę i profanujący ich świętości, i jeszcze domagający się za to przywilejów oraz oddawania mu czci. (DRz 2019, nr 25); Nadchodzą ciężkie czasy dla normalsów. Publiczna przestrzeń stała się, za sprawą komercyjnych firm, miejscem pełnym tęczowej propagandy przymuszającej heteryków do akceptacji homoseksualizmu. (DRz 2019, nr 31); Ukierunkowanie jej [= rewolucji LGBT] na uporczywe prowokowanie „normalsów” [...] ma sprowokować przeciw homoseksualistom odruch potępienia, a jak się da, to i agresji. (DRz 2019, nr 34); [...] Węgrzy [...]. Są jednym z najbardziej homosceptycznych narodów w Europie, bardziej niż Polacy. Jednym z czterech unijnych społeczeństw, których większość sprzeciwia się przyznaniu parom "nieheteroseksualnym” takich samych przywilejów, jakie mają normalsi. (S 2019, nr 42).

specjals 'członek sił specjalnych':

Resztą zajęła się wkraczająca do akcji sekcja angielskich „specjalsów”. (SP 2017, nr 44); [...] w tamtym rejonie [...] są nasi lotnicy i specjalsi [...]. (NCz 2018, nr 1-2); Specjalsi z wybrzeży Bałtyku [tytuł] Przyjrzyjmy się, jak wygląda funkcjonowanie specjalsów w państwach bałtyckich. [...] świadczy to o świetnej organizacji estońskich specjalsów. (GPC 2018, nr 52); Specjalsi na Falklandach [tytuł] (HbC 2018, nr 25); Specjalsi w wirze walk [tytuł] W Polsce mamy kilka jednostek specjalsów. (GPC 2018, nr 19); Wszak już od dawna nasze F-16 i nasi „specjalsi” stacjonują w tamtych stronach. (PN 2018, nr 8); Nowy dowódca specjalsów. (DzP 1 X 2018); [...] robimy to, co w naszym scenariuszu filmowym robi się na poligonach dla specjalsów [...]. (PN 2018, nr 19); Oddział „Grom” polscy specjalsi. (NH 2019, nr 3); Inspektorat Uzbrojenia poszukuje wozów dla specjalsów. [...] Pojazdy te mają zastąpić obecnie eksploatowane przez specjalsów pojazdy o wysokiej mobilności HMMWV. (GPC 2019, nr 130).

\section{terytorials 'członek Wojsk Obrony Terytorialnej':}

Terytorialsi doskonalą umiejętności [tytuł] (GPC 2017, nr 138); Terytorialsi zaś, jak sama nazwa wskazuje, przywiązani są do miejsca. (GPC 2017, nr 194); Terytorialsi coraz liczniejsi [tytuł] Z kolei w niedzielę na rzeszowskim rynku grupa 500 „terytorialsów” złożyła uroczystą przysięgę żołnierską. (GPC 2017, nr 278); Dlaczego zdecydowała się Pani wstąpić do terytorialsów? Ojczyzna to ludzie, a terytorialsi służą lokalnym społecznościom. Niedawno terytorialsi uratowali starszą panią i jej ukochanego psa z pożaru. (GPC 2018, nr 57); Terytorialsi ratują życie [tytuł] (GPC 2018, nr 136); I wcale nie ukrywa, że terytorialsi mają być jak specjalsi, a struktury WOT organizuje na wzór polskich specjednostek. [...] Terytorialsi zwierają swoje szeregi. [...] Pierwsze szkolenia terytorialsów w Małopolsce rozpoczną się jesienią. (DzP 30 IV 2018); Nowe brygady terytorialsów powstają zgodnie z planem. [...] W każdym województwie powstanie jedna brygada terytorialsów. (GPC 2018, nr 21); Drony uderzeniowe u terytorialsów [tytuł] [...] jeden z terytorialsów osiągnął najlepszy wynik 
na szkoleniu. [...] Dziś ułani bardzo starsi, za to są terytorialsi. (GPC 2018, nr 101); Czy Sącz potrzebuje terytorialsów? [...] Siedzibą tzw. terytorialsów mają być zabudowania Zespołu Szkół nr 2 [...]. (DzP 13 VIII 2018); Terytorialsi wyszkoleni, czekają na przysięgę. [...] Średnia wieku terytorialsów wynosi 32 lata. [...] Zauważyłem, że przybywa chętnych do bycia terytorialsem. (DzP 11 X 2018); Naszych czytelników interesuje sam proces rekrutacji terytorialsa. [...] Na czym polegają etapy szkolenia terytorialsa? [...] A co dzieje się w kolejnym roku szkolenia terytorialsa? (GPC 2019, nr 89); W tym czasie każdy terytorials wykona wiele zadań taktycznych. (NDz 2019, nr 93); Terytorialsi ruszyli jednak do walki z powodzią. [...] W ubiegłym tygodniu 70 terytorialsów działało na Podkarpaciu. [...] Przeciętny terytorials to mężczyzna w sile wieku. (DRz 2019, nr 22); Terytorialsi wyruszą z psami na ratunek zaginionym. (DzP 28 VI 2019); [...] program „Mieszkanie dla terytorialsa”. (TVPInfo 30 VII 2019); Do zadań żołnierzy należących do WOT-u, potocznie nazywanych terytorialsami, należy wspieranie ludności cywilnej ze swojej okolicy. (PN 2019, nr 10).

\section{totals 'członek totalnej opozycji':}

Krach według „totalsów” [tytuł] Niestety mimo chwilowego przełomu i teorii, która wlała nieco nadziei w serca „totalsów”, natychmiast na powierzchnię wypłynęły dwie wiadomości. Obie złe. (SP 2017, nr 41); Totalsi udowadniają, że żadne granice śmieszności dla nich nie istnieją. (WG 2018, nr 16); Obniżenie uposażeń posłów i samorządowców najbardziej zabolało totalną opozycję. [...] Zapewne, gdyby „totalsi” nadal byli przy władzy - takie zmniejszenie poborów o 20 proc. przyjęliby znacznie spokojniej; wszak to fachowcy od kręcenia lodów. (GPC 2018, nr 81); Zlot totalsów [tytuł] (S 2018, nr 4); Pamiętajmy, że dla totalsów nie są ważne ani nasza niepodległość, ani nasze wyborcze decyzje. (S 2018, nr 13); Czas odstawić totalsów na boczny tor już ostatecznie. (WG 2018, nr 18); W tym roku szczególnie przykre dla „totalsów” musiały być zdjęcia z punktu dojścia, placu Zamkowego [...]. Mam wrażenie, że „totalsi” powtarzają coś, co nazwałbym „klątwą Wałęsy”. (DRz 2018, nr 21); Kto głosuje na „totalsów”? (S 2018, nr 23); Mistrzostwa totalsów [tytuł] [...] czytelnik może uznać autora za jakiegoś abnegata albo totalsa, któremu wszelkie sukcesy Polski i Polaków bardzo przeszkadzają. Totalsi [...] chcą uczynić z radości Polaków [...] wykwit knajackości i prostactwa. (S 2018, nr 26); Oby nie stało się to w przyszłości argumentem dla totalsów, że każdą ustawę przyjętą przez polski Sejm można dowolnie modelować, gdy zaryczą lwy. (WG 2018, nr 27); Totalsi liczą na kolejny ruch Brukseli i na Europejski Trybunał w Strasburgu. (WD 2018, nr 28); [...] w głowach totalsów [...] tylko plażing, smażing itd. (PN 2018, nr 15); Dla medialnych sympatyków totalsów fakty większego znaczenia nie mają. (DRz 2018, nr 32); Totalsom udało się jedynie zbudować jeszcze większy mur między Polakami. (GPC 2018, nr 194); Ich program zdradziła też była premier i też kandydatka totalsów do europarlamentu - Ewa Kopacz. (S 2019, nr 14); Wyraźnie widać, że kalumnie, które rzucają przedstawiciele i akolici „totalsów”, działają na tzw. zwykłych Polaków jak płachta na byka. (S 2019, nr 26); Totalsi totalnie obrażą się na Polaków. (GP 2019, nr 23); Najbliższy cel: wygrać jesienią w bezdyskusyjny sposób, by temat zagrożenia ze strony totalsów zamknąć na amen. (WG 2019, nr 23); Jednak wszystkie te porażki nie zniechęciły „totalsów”. (DRz 
2019, nr 26); Wybór jest jasny: przedłużenie rządów PiS w imię rozwoju i stabilizacji albo chaos rządów niekompetentnych, a sfrustrowanych totalsów. (GPC 2019, $\mathrm{nr} 22$ ).

Wszystkie przytoczone wyżej wyrazy łączy jedna cecha wspólna. Każdy z nich pozostaje $\mathrm{w}$ języku polskim $\mathrm{w}$ relacji formalnoznaczeniowej $\mathrm{z}$ odpowiednim przymiotnikiem zakończonym na -alny: lokalny, milenialny, naturalny, normalny, specjalny, terytorialny, totalny. Ma to istotne znaczenie dla powstania innowacji słowotwórczej polegającej na wykształceniu się formantu obejmującego: 1) ucięcie części tematu przymiotnika, tj. cząstki - $n$-, i 2) dodanie sufiksu -s tworzącego formację rzeczownikową. Model ten został niewątpliwie zastosowany podczas tworzenia na gruncie polskim formacji: totals (totalny $\rightarrow$ total $<n>-s$ ) oraz specjals. W odniesieniu do rzeczowników lokals, naturals, normals, terytorials sytuacja nie jest jednoznaczna, niełatwo bowiem rozstrzygnąć, jaki udział w ich pojawieniu się w polszczyźnie ma czynnik obcy (tj. czy i w jakim stopniu mamy do czynienia z pożyczką leksykalną z języka angielskiego), jaki zaś rodzima derywacja. Wątpliwości nie budzi z kolei słowo millennials. Zostało ono bowiem bez wątpienia zapożyczone z języka angielskiego ${ }^{4} \mathrm{~W}$ formie liczby mnogiej (millennials) i poddane depluralizacji, stąd ang. millennial $=$ pol. millennials, $\mathrm{w}$ l.mn. millennialsi ${ }^{5} . \mathrm{W}$ podobny sposób, aczkolwiek sporadycznie, używane są zdepluralizowane anglicyzmy seals ${ }^{6}$ 'członek sił specjalnych marynarki wojennej USA'7 oraz royals ${ }^{8}$ pot. 'członek rodziny królewskiej”, por.:

Pierwszy ranny seals. [...] Znam was. Siostra zaręczyła się z sealsem. [...] Nie umawiasz się z sealsami. [...] Każdy seals jest mile widziany. (Ścieżka dialogowa filmu Snajper, emisja 31 V 2019 r. w TVN); A ja w swojej pracy nie mogę tylko ćwiczyć się w strzelaniu, muszę też pracować nad pozostałymi umiejętnościami, jak nurkowanie czy skakanie ze spadochronem, które są niezbędne sealsowi. [...] SEALs są wysyłani do najgorszych walk. [...] Zanim zostałeś sealsem, musiałeś przejść przez Hell Week, który odsiewa słabych i zostawia tylko najtwardszych. Jak ci się udało? [...] Potrafię być bardzo uparty, a zostanie sealsem było dla mnie najważniejsze na świecie. [...]

4 Por. millennial 'a person reaching young adulthood in the early 21st century' (https://en.oxford dictionaries.com/definition/millennial); 'a person born in the 1980 os or 1990 - usually plural' (https://www.merriam-webster.com/dictionary/millennial).

5 W polskich tekstach spotyka się trojaką pisownię: millennials, millenials, milenials.

6 Por. seal 'a member of the Sea Air and Land Teams, an elite special operations unit of the United States Navy' (in British English - CED); 'a member of a special U.S. Navy combat unit trained for sea, air, or land commando operations' (in American English - WCD) (https://www.collinsdictio nary.com/dictionary/english/seal).

7 Ten wyraz ze względu na wymowę samogłoski [i] lub [i:] w temacie różni się od pozostałych omawianych przykładów.

8 Por. royal [usually plural] 'members of the royal family are sometimes referred to as royals' [informal] (https://www.collinsdictionary.com/dictionary/english/royal).

9 Jednak nie odnoszą się one do polskich realiów i nie mają żadnych powiązań z polskim leksykonem w przeciwieństwie do millennialsa, który po przeniesieniu na grunt polski dołączył do obecnych w polszczyźnie latynizmów milenium, milenijny, milenialny. 
Nie ma kobiet sealsów? [...] Będąc sealsem, jesteś dwiema różnymi osobami. [...] Podobno procent rozwodów wśród sealsów wynosi 95. (https://www.wysokieobcasy. pl/wysokie-obcasy/1,53668,12393039,Zawod__snajper.html?disableRedirects=true);

Postarzyliśmy twarze 'royalsów'. 'Stara' Kate jest naprawdę piękna, a co z Meghan? (http://www.plotek.pl/plotek/56,79592,25004141,jak-bedzie-wygladac-meghan-na-starosc.html); Tatuaże royalsów (https://wielkarodzinakrolewska.blogspot. com/2019/o7/tatuaze-royalsow.html); Kto z royalsów niedługo odwiedzi Polskę? (https://wielkarodzinakrolewska.blogspot.com/2019/11/kto-z-royalsow-niedugo-odwiedzi-polske.html); Co powiedziałabyś spotkanemu royalsowi i kto by to był? (http://zblogowani.pl/wpis/4510073/liebster-blog-awards); Czy Zjednoczone Emiraty Arabskie przyjmą podejrzanego o molestowanie nieletnich royalsa $\mathrm{z}$ otwartymi ramionami? (https://www.pudelek.pl/przerazony-ksiaze-andrzej-ucieka-bentleyem-spod-palacu-buckingham-do-dubaju-foto-6448558802646657a).

Czy podobną drogę jak słowo millennial mogły przejść angielskie rzeczowniki local, natural, normal, territorial? Szczegółowa analiza kontekstowa polskich form wykazuje, że częściej możemy tu mieć do czynienia ze wspomnianą innowacją słowotwórczą. Skonfrontujmy zatem angielskie znaczenia wymienionych słów odnoszące się do człowieka z tymi, które aktualizują się w materiale wyekscerpowanym z polskich źródeł.

Słowo local w języku angielskim oznacza m.in. mieszkańca określonego obszaru, miejscowości, osobę miejscową, por.:

'An inhabitant of a particular area or neighbourhood' (https://en.oxforddictionaries. com/definition/local)

4. informal A person from a particular locality $(\mathrm{AH})$

6. an inhabitant of a specified locality (CED)

11. Often, locals. a) a local person or resident $(\mathrm{RH})$.

Można podejrzewać, że podobnie jak millenials zostało przejęte z języka angielskiego w postaci locals i zdepluralizowane, choć rodzimej derywacji jako czynnika sprawczego, przynajmniej w części użyć, nie można tu wykluczyć.

W wypadku wyrazu naturals można zauważyć jego nieadekwatność znaczeniową względem angielskiego rzeczownika natural, który słowniki definiują następująco:

19. informal a person or thing regarded as certain to qualify for success, selection,

etc.: the horse was a natural for first place. 22. obsolete an imbecile; idiot (CED)

4a: one having natural skills, talents, or abilities (MW)

24. a fool or idiot (RH). 
Jak widać, słowniki angielskie nie odnotowują znaczeń, które zauważamy w polskim materiale. Niewykluczone, że jedynie znaczenie związane z jeździectwem 'zwolennik naturalnego jeździectwa' jest przeniesione z języka angielskiego, jednak należałoby to dokładnie zweryfikować - pozostawiam to zadanie anglistom.

Jeśli chodzi o wyraz normals, słowniki języka angielskiego nie podają definicji znaczeniowych odnoszących się do człowieka. Prawdopodobne jest zatem, że funkcjonujący w polszczyźnie rzeczownik normals jest wytworem derywacji słowotwórczej. Być może angielski rodowód ma jedynie środowiskowe określenie normals nazywające przedstawicieli subkultury normcore, nieuwzględnione jednak w cytowanych słownikach.

$\mathrm{Z}$ kolei słowo terytorials zaczęło być intensywnie używane po utworzeniu w 2017 r. Wojsk Obrony Terytorialnej. Ma ono swój odpowiednik w języku angielskim $^{10}$, ale niewykluczone, że jego obecność we współczesnej polszczyźnie jest rezultatem opisanego powyżej zabiegu słowotwórczego.

Podsumowując tę część analizy, można stwierdzić, że z niewątpliwym zapożyczeniem leksykalnym mamy do czynienia w przypadku słowa millennials, z prawdopodobnym zaś w odniesieniu do wyrazu lokals i ewentualnie terytorials. Z kolei wyrazy totals i specjals są bez wątpienia rezultatami rodzimej derywacji z udziałem sufiksu -s, natomiast naturals i normals, z racji wyraźnej asymetrii znaczeniowej $\mathrm{w}$ porównywanych językach, w większym stopniu wydają się formacjami słowotwórczymi niż anglicyzmami leksykalnymi.

Kolejny problem to ustalenie genezy wymienionego sufiksu. Wywodzi się on niewątpliwie $\mathrm{z}$ języka angielskiego. $\mathrm{W}$ angielskich rzeczownikach pełni funkcję końcówki liczby mnogiej. Zjawisko przejmowania angielskiej końcówki pluralnej -s wraz z wyrazami zapożyczanymi jest znane od dawna. Zauważalna jest jednak istotna różnica. Otóż w formach takich jak drops, keks, klips końcówka ta została włączona do tematu (niepodzielnego słowotwórczo), w innych z kolei do sufiksu (por. sufiks -ers w formach typu blokers, bieszczaders, platformers, saczers, włóczkers, pidżamers). Mamy tu do czynienia z dobrze już opisanym zjawiskiem depluralizacji zapożyczonych rzeczowników angielskich (zob. Fisiak 1961), natomiast w przypadku analizowanych form nastąpiło wyodrębnienie -s jako sufiksu. Punktem wyjścia omawianej miniserii słowotwórczej mógł się stać przejęty $\mathrm{z}$ angielskiego wyraz millennials nazywający (po depluralizacji) przedstawiciela tzw. pokolenia Y (pokolenia ludzi urodzonych w latach 8o. i 9o. XX w.). Z racji przysługującego mu znaczenia od kilku lat jest bardzo często używany w różnego rodzaju tekstach publikowanych w mediach. O medialnej popularności omawianego zapożyczenia świadczyć może

10 Por.: territorial 'a member of the Territorial Army' (https://dictionary.cambridge.org/pl/dictiona ry/english/territorial). 
fakt, że wyszukiwarka Google podaje aż 292 ooo wyników dla hasła millennialsi ${ }^{11}$ (191 000 - millenialsi; 86300 - milenialsi). Trafił ów anglicyzm także do tytułów książek, których tłumaczenia ukazały się nakładem Wydawnictwa Naukowego PWN w 2018 r.: Zarzadzanie milenialsami (Chip Espinoza, Mick Ukleja), Milenialsi zarządzają (Chip Espinoza, Joel Schwarzbart). Pojawienie się w języku polskim omawianej serii wyrazów zbiegło się w czasie z zapożyczeniem tego właśnie wyrazu i jego wysoką frekwencją w tekstach, co może świadczyć o tym, że poddany depluralizacji, dekompozycji i refunkcjonalizacji morfologicznej miał wpływ na powstanie modelu słowotwórczego polegającego na tworzeniu rzeczowników odprzymiotnikowych za pomocą sufiksu -s. Warto zauważyć, że od połowy lat 8o. istniała w Polsce fundacja zajmująca się opieką nad zwierzętami, którą nazwano „Animals”. Jej członkowie nazywani byli potocznie animalsami ${ }^{12}$, a pojedynczy aktywista stawał się animalsem $^{13}$. Nie miało to jednak wpływu na system słowotwórczy języka polskiego. Ta potoczna nomenklatura funkcjonuje także zresztą obecnie, por.:

Zdaniem animalsów, na tej trasie nie powinny pojawiać się konie w ogóle. (DzP 6 IX 2018); [...] krótkich propagandowych filmów, regularnie nagradzanych na festiwalach „,animalsów”. (DRz 2019, nr 42).

Analizowane w tym artykule wyrazy są obecne w polszczyźnie od kilku lat. Nie zostały jednak odnotowane ani w najnowszym wydaniu Wielkiego słownika ortograficznego $P W N$ z 2018 r. (WSO), ani też w opublikowanym w tym samym roku Wielkim słowniku języka polskiego PWN (WSJP PWN). Nie znalazły się również $\mathrm{w}$ zbiorze haseł opracowywanego w IJP PAN Wielkiego słownika języka polskiego PAN (WSJP PAN).

Jako ciekawostkę warto przywołać fakt zastosowania sufiksu -s do utworzenia nazwy własnej Góralsi (od rzecz. góral), por.:

Przed majówkowiczami wystąpili „Mali Iwkowianie”, „Iwkowianie”, „Góralsi” ${ }^{14}$ oraz kabaret „Kałasznikof”. (DzP 4 V 2019).

Nasuwa się z kolei pytanie, czy omawiane wyrazy są neutralne stylistycznie, czy też raczej są formacjami nacechowanymi. Na drugą z wymienionych możliwości

11 Dostęp 15 XII 2019.

12 Por.: Najważniejszym osiągnięciem animalsów było doprowadzenie do zakazu tuczu gęsich wątróbek (http://fundacja-animals.org/historia/). Animalsami potocznie nazywano też w Polsce członków brytyjskiego zespołu rockowego utworzonego w 1963 r., por.: „Animalsi to jeden z najważniejszych zespołów lat 6o. XX wieku" (https://pomorska.pl/legendarna-grupa-the-ani mals-wystapi-w-inowroclawiu/ar/13777199).

13 Por.: Zostań Animalsem - Akademia dla studentów! (http://akademiaap.com/zostan-animal sem-2/).

14 W nazwach zespołów muzycznych Normalsi, Góralsi, a także Püdelsi (formacji utworzonej w 1985 r. przez Andrzeja „Pudla” Bieniasza i Franza Dreadhuntera) można zauważyć analogię formalną do spolszczonej wersji nazwy The Beatles, tj. Bitelsi. 
zdaje się wskazywać to, że nierzadko są one w tekstach ujęte w cudzysłów, czasami pojawia się określenie tak zwany, a raz nawet użyto kwalifikatora potocznie, por.:

Wyraźnie widać, że kalumnie, które rzucają przedstawiciele i akolici „totalsów”, działają na tzw. zwykłych Polaków jak płachta na byka. (S 2019, nr 26); [...] PiS ma dzisiaj tak duży i różnorodny elektorat, że znajdują się w nim także wyborcy mniej zdecydowani. To tzw. normalsi, którzy na co dzień nie żyją polityką i nie emocjonują się nią. (DRz 2019, nr 41); Do zadań żołnierzy należących do WOT-u, potocznie nazywanych terytorialsami, należy wspieranie ludności cywilnej ze swojej okolicy. (PN 2019, nr 10).

Nadto niektóre z analizowanych słów konkurują w tekstach z równie nacechowanymi synonimami. Mianowicie totals $\mathrm{w}$ języku polityki bywa zastępowany określeniem totalny lub totalniak, natomiast normals w slangu młodzieżowym miał swoje odpowiedniki w postaci słów zwyklak i normik, por.:

Spróbujmy więc pomóc totalnym poradzić sobie z ich dysonansami poznawczymi [...]. (DRz 2017, $\mathrm{nr}$ 41); Msza pogrzebowa miała coś z małostkowości i hipokryzji totalniaków. To niejedyne takie wejście totalniaków w coś, czego teoretycznie nie znosili. (WG 2019, nr 4); W kategorii „słowo ciekawie zbudowane” wyróżniamy wyraz zwyklak. Rzeczownik o oczywistej strukturze, podobny do nieco starszego normika pojawił się w sieci dopiero przed rokiem. Nie każdy musi być prestiżowy. Zwyklaki i normiki też są na świecie. (https://sjp.pwn.pl/mlodziezowe-slowo-roku/haslo/ Rozstrzygniecie-plebiscytu-mlodziezowe-slowo-roku-2018-komentarz-Marka-La zinskiego;6477396.html).

Liczne prace na temat zapożyczeń angielskich w polszczyźnie (np. Mańczak-Wohlfeld 2010; Witalisz ${ }^{15}$ 2016; ostatnio Dunaj 2017: 70-73; Dunaj, Mycawka 2017) jednoznacznie dowodzą, że wpływy języka angielskiego zaznaczają się najsilniej w sferze leksykalnej. W pewnym zakresie oddziaływanie angielszczyzny obejmuje również słowotwórstwo. $Z$ zapożyczonych angielskich derywatów bywają wyabstrahowywane sufiksy służące do tworzenia nowych form od podstaw rodzimych. Innym zjawiskiem jest tworzenie złożonych struktur za pomocą pseudosufiksów (zob. Witalisz 2016: 133-139).

Jeśli chodzi o angielskie sufiksy służące do tworzenia w polszczyźnie rodzimych formacji, to na szczególną uwagę zasługują derywaty z sufiksem -ing typu gwatting, molesting, schoding, łomżing, plażing, smażing (zob. Mańczak-Wohlfeld 1993: 281; Witalisz 2016: 133-134). Inny przykład oddziaływania języka angielskiego na polską morfologię dotyczy nazw własnych. Chodzi tu o angielski sufiks hipokorystyczny -i, który bywa dodawany do polskich imion lub nazwisk,

15 Jestem winna podziękowania Pani Profesor Alicji Witalisz za przeprowadzenie kwerendy w słownikach anglojęzycznych, której rezultaty odnoszące się do trzech wyrazów zostały uwzględnione $\mathrm{w}$ niniejszym artykule. 
por. np. Hubi ${ }^{16}<$ Hubert, Mati < Mateusz, Pati < Patrycja, Maki (od nazwiska Makuszewski), Oszi (od n. Oszmaniec), Saki < Sakiewicz, Zati (od n. Zatorski) (zob. Dunaj 2009). Analizowany w niniejszym artykule afiks różni się od powyższych tym, że w języku angielskim jest to morfem fleksyjny, natomiast w języku polskim pełni on funkcję przyrostka słowotwórczego.

\section{Źródła}

DzP - „Dziennik Polski”

DRz - „Do Rzeczy”

GP - „Gazeta Polska”

GPC - „Gazeta Polska Codziennie”

GW - „Gazeta Wyborcza”

$\mathrm{HbC}$ - „Historia bez Cenzury”

$\mathrm{NCz}$ - „Najwyższy Czas!”

$\mathrm{NH}$ - „Nasza Historia”

PN - „Polska Niepodległa”

$\mathrm{S}-$ „Sieci”

SP - „Sieci Prawdy”

TVP I - Telewizja Polska, program I

TVPInfo

WG - „Warszawska Gazeta”

WS - „WSieci”

\section{Literatura}

AH: W. Morris (red.), American Heritage Dictionary of the English Language, wyd. 5, Boston 2011.

CED: Collins English Dictionary. Complete and Unabridged, wyd. 12, Glasgow 2014.

Dunaj B., 2009, Formy derywowane imion z zapożyczonym sufiksem -i, [w:] M. Skarżyński, M. Szpiczakowska (red.), W kręgu języka. Materiały konferencji „Słowotwórstwo słownictwo - polszczyzna kresowa" poświęconej pamięci Profesor Zofii Kurzowej. Kraków 16-17 maja 2008 r., „Biblioteka LingVariów”, t. 2, Kraków, s. 67-75.

Dunaj B., 2017, Zmiany w słownictwie polskim po 1989 roku, [w:] M. Pachowicz, K. Choińska (red.), Świat słów. Jedność w różności, Tarnów, s. 53-78.

Dunaj B., Mycawka M., 2017, O potrzebnych i niepotrzebnych zapożyczeniach z języka angielskiego, „Annales Universitatis Paedagogicae Cracoviensis. Studia Linguistica” 12, s. 67-79.

16 „Trzeba tu zauważyć, że derywaty męskie są włączane do fleksyjnego paradygmatu przymiotnikowego i w konsekwencji odmieniane [...]. W rezultacie w formach męskich mamy do czynienia na gruncie języka polskiego z derywacją paradygmatyczną, por. Mati, Matiego, Matiemu" (Dunaj 2009: 321). 
FISIAK J., 1961, Zjawisko depluralizacji niektórych rzeczowników angielskich zapożyczonych przez język polski, „Język Polski” XLI, s. 138-139.

Goffman E., 2005, Piętno. Rozważania o zranionej tożsamości, tłum. A. Dzierżyńska, J. Tokarska-Bakir, Gdańsk.

MAŃCZAK-Wohlfeld E., 1993, Uwagi o wpływie języka angielskiego na polszczyznę końca $X X$ w., „Język Polski” LXXIII, s. 279-281.

MańCZAK-Wohlfeld E. (red.), 2010, Słownik zapożyczeń angielskich w polszczyźnie, Warszawa.

MW: Merriam-Webster's Collegiate Dictionary, wyd. 11, Springfield 2004.

RH: Random House Webster's College Dictionary, New York 2010.

WCD: Webster's New World College Dictionary, wyd. 4, Boston 2010.

Wielki słownik języka polskiego PAN. Geneza, koncepcja, zasady opracowania, praca zbiorowa, red. P. Żmigrodzki, M. Bańko, B. Batko-Tokarz, J. Bobrowski, A. Czelakowska, M. Grochowski, R. Przybylska, J. Waniakowa, K. Węgrzynek, Kraków 2018.

Witalisz A., 2016, Przewodnik po anglicyzmach w języku polskim, Kraków.

WSJP PAN: P. Żmigrodzki (red.), Wielki słownik języka polskiego PAN, [on-line:] wsjp.pl.

WSJP PWN: S. Dubisz (red.), Wielki słownik jezzyka polskiego PWN, t. I-V, Warszawa 2018.

WSO: E. Polański (red.), Wielki słownik ortograficzny PWN z zasadami pisowni i nterpunkcji, wyd. 4, dodruk popr., Warszawa 2018.

\section{Formations with the -s Suffix: normals, terytorials, totals Summary}

In recent years, there appeared in Polish a series of words ending in -als. One of them is the word millennials, a lexical borrowing from English, which has been depluralized in Polish and is represented by the forms millennials - milllennialsi. Other words with a similar structure include lokals, normals, naturals, specjals, terytorials, totals. A part of them have arisen as a result of word-formation with the English suffix $-s$. The paper contains an analysis of these words, and attempts to answer the question how these words were created, and in what meanings they function in contemporary Polish. 